\title{
Dán dizájn az oktatásban - beszámoló az Erasmus+ oktatói látogatásról a VIA University College-ban
}

\author{
ÁrVA VALÉria \\ Eötvös Loránd Tudományegyetem Tanító- és Óvóképző Kar, Budapest
}

\begin{abstract}
Cikkemben beszámolok a VIA University College-ban tett oktatói Erasmus látogatásomról, melynek során mélyebb betekintést nyertem az aarhusi tanitóképzési programba és az intézmény nemzetköziesitési folyamataiba. A látogatásom során megismerkedtem két újonnan épitett, kiemelkedö színvonalú oktatási épülettel, a VIA University College új, belvárosi campusával és egy stjerneni általános iskolával, melyek különös jellemzöje, hogy a tervezés során az épitészek és az ott dolgozó oktatók-tanárok szorosan együttmüködtek.
\end{abstract}

Kulcsszavak: Erasmus, nemzetközi, Aarhus, oktatás, épitészet

2017. április 24. és 28. között Erasmus+ tanári mobilitás keretében a dániai Aarhusban található VIA University College-ben tettem látogatás. Szerencsém volt, ugyanis az angol gyermekirodalom módszertani óráimon kívül a héten zajló Nemzetközi Hét programjain is részt tudtam venni: az egyetem tanitó- és tanárképző karán ekkor fogadták az adminisztratív program keretén belül a lengyel, román és török Erasmus partner egyetemekről érkező kollégákat. A gazdag, egyhetes programnak köszönhetően mélyebben megismerhettük a karon történő oktatást, bejártuk a nem mindennapi, két évvel ezelőtt átadott, több építészeti díjat nyert egyetemi épületet, bemutatták múzeumpedagógiai programjukat, valamint a dán közoktatásról és a pedagógiai kutatási projektekről értékes ismereteket szerezhettünk.

Aarhus a második legnagyobb dán város, ami Jutland szigetén helyezkedik el és háromórás vonatúttal érhető el Koppenhágából. A régi kikötőváros 2017-ben Európa kulturális fővárosa. Jelentős modern építészeti művekkel rendelkezik, melyek közül különösen figyelemre méltóak a jéghegyre emlékeztető lakóházak a kikötőben, a szivárványpanorámájú folyosó a szépművészeti múzeum tetején, a hangversenyterme és a lyukkártya formájú kilátó. Hangulatos belvárosa jelentős kereskedelmi központ.
A régi Ceres sörgyár területén elhelyezkedő belvárosi campust 2015-ben adták át. A campus épületei térben is megjelenítik a 21. századi egyetemi oktatás elveit: átriumszerü, nyitott, központi, közösségi terek jellemzik, ahol lépcsőszerű emelvényeken időzhetnek a diákok, villanykonnektorok sokasága biztosítja számítógépeik, telefonjaik töltését, üvegfalú, átlátható tantermek, önálló tanulást, csoport- vagy projektmunkát szolgáló terek és tanári szobák nyílnak a mátrixszerűen elrendezett épületek belső folyosóiról. Az aarhusi, hideg éghajlaton szerencsés, hogy az épületeket folyosók kötik össze. A könyvtár két szintet foglal el az átriumra néző teraszokból, és 24 órás önkiszolgáló rendszerben használható - ugyanígy az épületbe is $0-24$ órás bejárásra van lehetősége a diákoknak és az oktatóknak egyaránt.

Az épület tervezési folyamatába bevonták az egyetem oktatóit, például így volt lehetősége egyes tanszékeknek egyterű tanári szobákat kérni, mások inkább kisebb, néhány személyesre tartottak igényt. A diákok további kényelmét szolgálják a több helyen megtalálható konyhaegységek, valamint a számunkra már elképzelhetetlen luxusnak tűnő oktatói közösségi terek, melyek közül egyben volt szerencsénk időt tölteni: kanapékkal, minikonyhával, étkezővel, konferenciasarokkal és hihetetlen módon még egy zongorával 
is fel volt szerelve. A diákok vállalkozásaikat, melyek akár oktatással kapcsolatosak is lehetnek, az egyetemi „inkubátorban” indíthatják be. További hátterinformáció és képek az egyetemről a következő linken találhatóak:

http://www.archdaily.com/774183/ via-university-college-aarhus-cityarkitema-architects

A VIA University College Dánia egyik legfontosabb tanár- és tanítóképző intézménye. Az Erasmus ösztöndíjjal érkező diákoknak speciális nemzetközi oktatási programot állítanak össze. A nemzetköziesítés kiemelt szerepet játszik a VIA életében: nem csak az Erasmus program keretében fogadnak és küldenek diákokat, hanem egy kínai egyetemen is folytatnak pedagógusképzést: a kínai diákok tanulmányaik első három évében párhuzamosan végzik a kínai és a dán programokat, majd az utolsó évet Aarhusban töltik. Ez az együttmúködés azért jött létre, mert a kínai oktatási hatóságok 'humanizálni' szeretnék oktatási rendszerüket és erre Dániában találtak megfelelő partnereket.

A karon a nemzetköziesítés keretében nem csak a külföldi diákok bevonzását tartják fontosnak, hanem saját diákjaik külföldi tanulmányait is szorgalmazzák. Mivel a dán diákok jellemzően jól beszélnek angolul, az egyetem az a célt tűzte ki, hogy a hallgatók a három hathetes tanítási gyakorlatuk közül az egyiket, lehetőség szerint a másodikat, ami a harmadik évben van, külföldön végezzék. Mivel ehhez folyamatosan keresnek partner iskolákat, Budapesten megkerestem néhány két tanítási nyelvű általános iskolát, akik mind jelezték, hogy örömmel fogadnák a dán tanárjelölteket.

A dán oktatási rendszernek csak néhány érdekességét emelném ki. Saját elmondásuk szerint három szóval lehet legjobban jellemezni: gondolkodás, játék és aktív részvétel. A tanárképzési programok egyik fó célkitüzése pedig olyan tanítók és tanárok képzése, akik majd úgy nevelik a gyermekeket, hogy azok felnőtt korukban a demokratikus társadalom aktív szereplőivé váljanak. Ez a cél többször és nagyon hangsúlyosan szerepelt a dán pedagógiai szakemberek előadásaiban.
Megtudtam azt is, hogy a dán oktatási rendszerben van egy olyan különleges év, amilyenről még egy országban sem hallottam. A diákoknak tizenöt éves korukban lehetősége van a kilencedik évfolyamot egy bentlakásos iskolában tölteni. Az egyébként az óvodától az egyetemig ingyenes rendszerben az az egyetlen év, amiért tandíjat kell fizetni. Elmondták, hogy ezzel a lehetőséggel hozzávetőleg a diákság fele szokott élni. Ezekben a bentlakásos iskolákban az akadémiai tárgyak helyett a művészeti nevelés és a sport, valamint a közösségek kialakítása áll a középpontban. A diákok között olyan szoros kapcsolatok alakulnak ki az év során, amelyeket nem ritkán egész életük során megőriznek. A program többek között a szülőktől való elszakadást és az önállóságra való nevelést segíti elő.

A programnak egy iskolalátogatás is része volt: a körülbelül hatvan kilométerre fekvő Stjernen városkában található óvoda-általános iskola komplexumot tekintettük meg. Az iskola egy néhány éve átadott, új épületben működik és sok szempontból átlagos intézmény, de az épület még dán viszonylatban is különlegesnek számít: az építész az iskola és az óvoda igazgatóinak pedagógiai elképzelései alapján tervezte. Az eredmény egy csillagalakú épület: a középen fekvő közös térből nyílnak a csillag szárai, melyekben a bölcsőde, az óvoda és az általános iskola működik. Két szárny még megépítésre vár, ezekben fog a konyha és a középiskola működni. Mivel az épület padlója faburkolatú, a gyerekek mezítláb járkáltak, akárcsak a látogatók és mindannyian sokkal otthonosabban éreztük magunkat. Számtalan apró részletet alakítottak ki, melyek mind a tanulást és az otthonosabb iskolai létet segítik elő, ezekre csak egy példa a tantermekben kialakított többszintes dobogószerü beszélgetősarkok, melyek a folyosón kuckóként jelennek meg, mint a belső tér negatív lenyomatai.

A következő linken az építészeti tervekről található egy diavetítés https://tjoerringnyskole. files.wordpress.com/2011/09/presentation-forwaf_reduced.pdf, illetve egy negyven másodperces, angol feliratos videó: http://tjoerringskole.skoleporten.dk/sp/p286254/text/Om\%20 Stjernen 
Dán dizájn az oktatásban - beszámoló az Erasmus+ oktatói látogatásról...

Az Aarhusban töltött egy hét alatt szerzett szemesztert, újszerű ismeretekkel és pedagógiai tanítási tapasztalatok meggyőztek, hogy hall- tapasztalatokkal gazdagabban térhetnek haza. Az gatóink, akik Erasmus+ hallgatói mobilitás- egyhetes program pedig az egyetem alaposabb sal a VIA University College-ban töltenek egy megismerésére teremtett alkalmat.

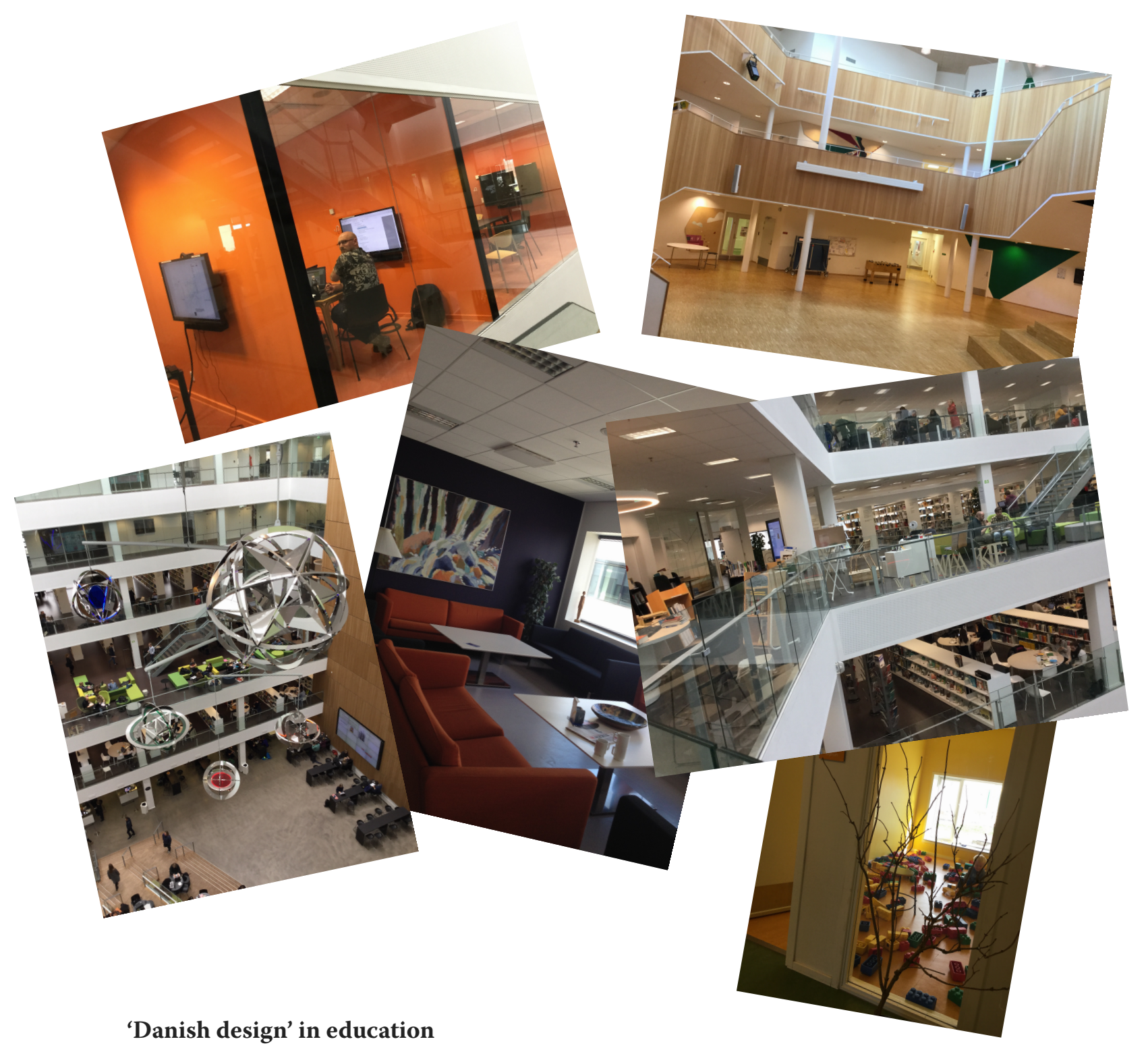

In my article I give account of my Erasmus staff mobility visit at VIA University College, Aarhus, through which I gained insight into the primary teacher training programme and processes of internationalisation there. During my visit I became acquainted with two newly built, educational buildings of outstanding quality: the new, inner city campus of VIA University College and a primary school at Stjernen. What makes these buildings different is that both of them were planned and designed in close cooperation between architects and teachers working there.

Keywords: Erasmus, international, Aarhus, education, architecture

Árva Valéria (2017): Dán dizájn az oktatásban - beszámoló az Erasmus+ oktatói látogatásról a VIA University College-ban. Gyermeknevelés, 5. 3. sz., 115-117. 